МЕДИАТЕКСТ:

СТРУКТУРА, КОМПОЗИЦИЯ, ВЕКТОРЫ ОБНОВЛЕНИЯ

UDC 81'42

\title{
The System of Russian Contemporary Media Discourse Media Toposes as a Reflection and a Transformation of Russian Cultural Archetypes
}

\section{V. Annenkova}

Moscow State University,

9, Mokhovaya str., Moscow, 125009, Russian Federation

For citation: Annenkova, I. V. (2019). The System of Russian Contemporary Media Discourse Media Toposes as a Reflection and a Transformation of Russian Cultural Archetypes. Media Linguistics, 6(1), 87-102. https://doi.org/10.21638/spbu22.2019.107

The article focuses on a discussion that the media rhetoric approach to the study of modern practices in media discourse should be included in a new paradigm of linguistic disciplines concentrated on the person speaking. The problem of formation of media topics in modern media is discussed on the basis of existing archetypical toposes of Russian culture. Interpretation and transformation of the national system of topics are one of the sides of the strategic activities of modern media, forming a new picture of the world, the media picture of the world. The example of 'Ukraine' as a new media topos is used to understand the processes of change in mental dominant of contemporary consciousness of Russians. Verbal play related to the sphere of this media topos demonstrates primarily targeting of such a speech behavioral dominant as aggression and is expressed in a creative invective. Such discursive practice becomes normal for Russian-speaking environment (especially on the Internet) and clearly demonstrates the most significant function of the mass media, the function of ideological argumentation. This is a universal media-discursive function which can be derived from the analysis of Russian, Ukrainian, and international media space. It is in line with the most important media discursive strategies of desacralizing and hedonizing. This phenomenon is regarded as ambiguous. Furthermore, it transforms and distorts archetypical dominants in people's mentality. Monitoring the creative invective as an instrument of destruction of archetypical culture dominants from within is of paramount significance.

Keywords: media topos, media discourse, verbal play, naming, creative invective.

(C) Санкт-Петербургский государственный университет, 2019 
Problem Statement. There is no doubt that now humanity is going through a new stage in the development of academic thought and science in general: the stage of neopositivism (V. V. Krasnykh). Though it is quite difficult to give a clear definition of this phenomenon (and concept), one can attempt to comprehend and structure a new academic reality (mostly, in the field of the Humanities). Neo-positivism is probably based on the following postulates (these postulates were proposed by V.V. Krasnykh):

1) Modern object of research, which, according to V. Telia, is still being created, cannot be "atomic", i. e. it cannot be detached from a broad historical and sociocultural context and should be discussed not per se but only taking into account this context and within this context;

2) Modern studies should be of holistic nature, i. e. on the one hand, they should be whole and systematic themselves, on the other hand, they should consider their object as integrated and integral, while at the same time being multi-component, mosaic, and kaleidoscopic, though internally linked;

3) At the same time both the multiplicity and multidimensionality of the object are recognized together with the pluralism of opinions of different researchers who are representatives of different schools and disciplines that study this object from different perspectives;

4) Study of the modern object of research (given its complexity and multidimensionality) within the framework and from the position of different disciplines is recognized as a natural continuation of the development of a human being (of their spiritual, intellectual and scientific development) and as a vital condition for human existence. This is largely due to the fact that different disciplines provide a variety of data, and the interaction of different disciplines is an important source of new knowledge and the basis for discovering and/or building new objects of research;

5) Such an interaction of different disciplines (including specialized disciplines) predetermines further development of science as such.

What is this new subject of research? It is quite obvious that it is concentrated on the human being as a unity of intellectual and spiritual capacities. The anthropocentric paradigm of modern academic thought research (philology in particular) presents the human being as its new subject. It is obvious that the orientation towards communication in contemporary linguistic research is the expression of that interest in the person speaking (homo loquens). Many scholars note that while the twentieth century was a century of high tech, the twenty-first century will be the century of high homo [Krasnykh 2017: 13-14].

Thus, according to many scholars, "the speaking human being is a person, one of whose activities is the speaking activity. On the one hand, a human being is an object of language, culture, linguoculture, community, and communication, because they are formed as a person, a bearer of consciousness, and as a full member of a certain community in communication: they absorb the culture of this community, primarily through the language spoken in this community, mastering, assimilating and appropriating to the linguoculture. On the other hand, they are also the subject of language, culture, linguoculture, and communication, because they themselves are the carrier of consciousness and language, "weaving within themselves" (V.von Humboldt) language, culture, and linguoculture, and "weaving themselves" into the language, culture, and linguoculture. 
Historical Background. In terms of philological knowledge today this approach is simultaneously represented in several directions. This is well demonstrated in the new collective monograph "(Neo)Psycholinguistics and (Psycho)Linguoculturology: the New Sciences about the Person Speaking" by I. A. Bubnova, V.V. Krasnykh, N. V.Ufimtseva, and I. V.Zykova [Bubnova, Krasnykh, Ufimtseva et al. 2017]. In the foreword to the monograph V.V.Krasnykh concisely and accurately characterizes new directions in academic research among which are ethnopsycholinguistics, neopsycholinguistics, psycholinguistics, linguoculturology, and cognitive linguoculturology. She states that 'according to N.V. Ufimtseva, "the central problem" of EPL ([ethnopsycholinguistics]) as for the "new methodological basis for ethnopsycholinguistic research", which began to emerge in Moscow psycholinguistic school in the early 90s, is the research of ethno-cultural specificity of linguistic consciousness, and the EPL itself focuses on studying the image of the world and its changes "from one culture to another"' [Krasnykh 2017: 16]. Therefore, ethnopsycholinguistics studies culturally marked features of linguistic consciousness. Neopsycholinguistics, or psycholinguistics of a person, focuses on the individual image of the world. Linguoculturology as an independent discipline studies "live communicative processes and connection of linguistic expressions used in them to the synchronously acting mentality of the people"; its focus is on the mundane picture of the world. Psycholinguoculturology is an entirely new direction, which is focused on the study of linguoculture and the person speaking in all their manifestations and contexts (including cultural, social, and political contexts) that form the personality of the human being. Cognitive linguoculturology looks ahead to "cognitive mechanisms of linguocreativity and macrometaphorical conceptual models" [Krasnykh 2017: 17]. Within the framework of this discipline the existence of one basic conceptosphere, the conceptosphere of culture, is recognized. It is created by the human being as a creating person who "preserves" the value content of this conceptosphere in language. In this particular philological discipline special attention is given to the phenomenon of linguocreativity and phraseocreativity which will be discussed below [Kreuz, Roberts 1995].

In continuation of all the above-mentioned the peculiar "interest" of rhetoric (neorhetoric and mediarhetoric) is worth noting in this integrated process of academic disciplines studying the person speaking. In this sense such a component of rhetorical argumentation as toposes happens to be in demand for the analysis of formation and transformation of the image of the world, which is reflected in the linguistic consciousness of both an individual and all the people or the whole nation [Habermas 2008; Pavlova 2013].

Toposes and the toposphere of national consciousness in mediadiscursive activity have been discussed many times. It is the interpretation of the national archetypical topic that sets paradigmatic shifts in people's mentality. One of the mostly principled ideas repeatedly expressed in my previous works is that "[i]n a complex interpretational system, which is schematically expressed by the dichotomy of reality and text, concepts of culture are not as much interpreted as its toposes. This is primarily due to the differences that exist between the ideas of concept and topos and which are determined by the specific differences between linguistics and rhetoric. The concept is a reflection of the speech-thoughtcognitive activity of a person, a cognitive concept. The culture topos is a reflection of an appraisal-comparative cognition, the ethical and moral paradigm of a nation "[Annenkova 2011: 87-88]. 
The idea has been expressed previously and is in many respects intersecting with the G. G. Khazagerov opinion which he has constantly been postulating promoting the idea of rhetorical comprehension of culture: "[i]f we assume that concepts frame the crystal lattice of culture, and toposes are the framework of communication, i.e. of that same culture but taken in its most important dimension, then, it must be recognized that toposes are subjected to transformations in the first place. It is the changes in toposphere that most flexibly reflect the shifts in public consciousness. Communicative models set by the social topic affect communicative reference points directly in routine behavior" [Khazagerov 2009]. G. G. Khazagerov gave a pretty interesting example of such an influence stating that "Whorf, an insurance agent and one of the authors of the famous Sapir-Whorf hypothesis, once noticed that people do not insure empty fuel barrels. It turns out that people are disoriented by the word "empty". Yet the number of fires did not decline. The domination of prejudice over consciousness is not identical with the domination of prejudice over life "[Khazagerov 2009].

The language data and the language image of the world reflected in the etymology, in the "internal form of the word", ultimately cannot affect human behavior. However, it is evident that verbal formulas affect human behavior to a greater extent. And this impact, shall we say, is short lived and more direct [Khazagerov 2002].

Material Analysis. For instance, the verbal formula "Russians do not surrender" is quite recent and was coined only in 1914 (during the First World War while defending the Osowiec fortress) but seamlessly intertwined into the communicative paradigm of Russians who had and still have to engage in ongoing hostilities. Russians have always been at war and are battling a lot! This verbal formula characterizes and predetermines a typical behavioral norm of the bearers of Russian self-consciousness, Russian culture and the Russian language. It is interesting to follow the interpretation of this norm regarding the topic of Ukraine in general and the conflict in Ukraine in particular.

It should be noted that today Ukraine can be regarded as a media topos, i. e. a media topic of particular cultural and political significance. Besides, this media topos exists not only in domestic (both Russian and Ukrainian) but also in international media. This point will be revisited below. It should now be emphasized that media topics and culture toposphere are not identical concepts. They should be rather referred to as overlapping (regarding the terminology of logic and stylistics). Since toposphere and content mean different things, it should immediately be stated that it is important to address the ways in which the Ukraine topic and topos are being discussed in the media. Therefore, communicative tactics that design the communicative strategy for the formation of the state-ideological dominant in mass consciousness are of paramount importance here. It is the new "Ukraine" media topos as a content and value dominant of the modern media discourse that seems to be indicative for the transforming image of the world and the linguistic consciousness of Russians. (Nowadays, there is another significant and essential media topos in media discourse, which is "Syria". Yet in its word-form it's dubious that has a comparably powerful influence on the consciousness and subconsciousness of speakers of the Russian language as the word Ukraine and is not subject to comprehension, interpretation, and transformation as an archetypical one because it can be recognized as neomediatopos and an emerging neotopos of culture).

In fact, Ukraine both as a topos and a media topos is a relatively new phenomenon; it emerged as a topos no more than two hundred years ago. There is no need to dwell on 
how this nomination emerged, formed or developed in both the Russian language and Russian culture. Many educated people still resist this word as a name of a certain territory but they cannot deny that there is an existing nation with this name. In the linguistic consciousness of the majority of Russians (and primarily Russian citizens) Ukraine is still perceived as a historical part of Russia (no matter whether it is called the Russian Empire or the USSR) and as a common with Russia geographical and cultural territory. This very kind of interpretation of the archetypical formula "Russians do not give up!" is seen in a joke from 2014 that emerged due to the events in Crimea:

A military unit in Crimea is surrounded by "vezhlyvie liudi" [polite people] that advise everybody to surrender. A Ukrainian national flag is raised over the building with shouts: "Russians do not surrender!"

It is important to note that this joke first appeared on the Russian Internet. This is yet another evidence of two facts. First, subconsciously Ukrainians still regard themselves as Russians, as bearers of Russian culture (not all but the majority of them); second, the inhabitants of Russia regard the inhabitants of Ukraine as carriers of archetypical features common for all representatives of the Russian world.

At the same time, the very accentuation of this exact "unity" leads to serious reflections, such as that a healthy person is not thinking about his or her health or about the unity of hands, legs, head, or body... These are symptoms of a disease. When considering a single national mental environment, it is clear that these symptoms are inherent in both parties. How does the disease manifest itself? In our linguistic and discursive practice. First of all, in invectives. Direct insult is not so much considered here as, so to speak, a creative invective which is embodied in the invective function of the language play. It should be noted that it is not the official media who drive the formation of this function, but rather the mass audience that is present on social networks in the interactive of online media in the form of comments. The examples given below are of invective nominations not systematized depending on derivational, grammatical, or tropeic models:

Ukraine: Okraina [referring to outskirts], Urkaina [referring to bandits], Ukradina [referring to stealing], Uk-Ruina [referring to ruining], Durkaina [referring to stupidity], Zombie-Jukrain [referring to zombies], Banderland [referring to Bandera], Ukrowehrmacht [referring to Nazi Wehrmacht], ukrarium [referring to aquarium/terrarium].

The processes in Ukraine: evrookkupaciya [referring to European occupaiton], Evromajdan [referring to Europe], evreookkupaciya [referring to Jewish occupation], Evremajdan [referring to Jews].

Ukrainians (Ukraine citizens who are aggressive towards Russia and Donbass): hohliugi [referring to thieves], khokhlozavri [referring to dinosaurs], hohlolemmingi [referring to lemmings], ukropiteki ("Neither for themselves nor for anyone else" is a notable feature of ukropitek") [referring to primitive populations], ukrlyuftvaffovec (this nomination appeared after a Malaysian Boeing was shot down in the Donbass airspace) [referring to Nazi Luftwaffe], ukrofashisti [referring to fascists], bratoubijci [referring to fratricide], ukrozhlobi and hitroumnie okrainci (in materials on Russian gas) [referring to schlubs and ingenious Greeks in Homer's "Odyssey"], huntoidi [referring to junta and primitive creatures], huntyata ("American-Ukrainian junta") [referring to junta], huntari [referring to mutinied junta], ukrop [referring to fennel], ukropejskij [referring to fennel], ukropeec [referring to fennel], ukrofashist [referring to fascists], kakly [referring to poop], edinoukrainci [referring to "the United Ukrainians"], ukrarii [referring to herbarium, thus, to dried 
up plants], hataskrainiki (here they clearly refer to the topical formula "my crib is on the edge" which means "it is not my business") [referring to the previously mentioned idiom], neobanderovci [referring to Stepan Bandera], galitsai [referring to Nazi police], schenevmerliki [referring to the Ukrainian anthem], skakuni-papuasi banderovskie [referring to horseback riders, Papuan people, and Stepan Bandera], evrointegreri [referring to European integration], lala-zombi [referring to chatty blabbermouth zombies].

Nomination of Ukrainian politicians or those who are directly or indirectly associated with the events happening in Ukraine demonstrates active naming processes in mass media which can be characterized as a creative invective:

Turchynov: Trupchinov [referring to a corpse], Tupchinov [referring to stupidity];

Poroshenko: Potroshenko [referring to gutting], Porazhenko [referring losing in a battle];

Victoria Nuland: baba Nulya [referring to zero and Yulia Tymoshenko];

Yulia Tymoshenko: baba Yulya [addressing to her informally].

Here is a small quotation with a whole set of denominations within the "Ukraine" media topos: "[a]fter signing the euro...ssatsiya [referring to pissing] the inhabitants of the territory are called khokhlopeitsi [referring to europeans]. And let maidauni [referring to Down's syndrome] not forget that those who will not be "koloradi" [referring to a potato beetle] will forever be with "kolomoyshi" [referring Igor Kolomoyskyi and Moyshe]".

Naming creativity demonstrates the formation of both neoprecedence and, therefore, of denomination linked to this new cultural context. If the "hitroumnie okrainci" refers to the Odyssey of Homer, the groundwork of world literature, the expression "visiting grandmother in Russia" obviously hints at the press conference of the US State Department spokeswoman Jen Psaki and at her comments on military operations and refugees in Donbass. It is the speech cases related to commenting on the Ukrainian crisis that gave rise to such denominations as "obaming" [referring to Barack Obama], "psaking" [referring to Jen Psaki and pissing], "naitemnejshij" [referring to Barack Obama and in this way opposing him to Putin], or "Obama psakied" [referring to Jen Psaki and pissing].

As it can be seen from the examples provided, from the linguistic point of view, all those models that are used to form units of naming are not new [Goddard 2008]. Emotional and evaluational affixation, creation of words with the neo- prefix, with the root -euro-, creation of words with an English suffix -ing- to denote this process in the Cyrillic script, the use of suffixes of superlative forms, creation of new abbreviations (for example, $M M M$ for mass misinformation media), truncation (Dnipro instead of Dnipropetrovsk), etc.; all these techniques are well known. However, it should be clear that naming functions are always predetermined by its tactics. The following tactics should be highlighted among those: 1) purely legal tactics (the actual denomination in the absence of available names for a certain concept), 2) tactics caused by internal laws of the language and, above all, by the laws of saving on communication tools, 3) linguoculturological tactics, 4) ludic tactics, 5) argumentation tactics. Through the analysis of the examples discussed and the content of the modern Internet it can easily be concluded that the first two tactics of naming are barely represented in the modern word-making process regarding the "Ukraine" topos. The only exception is the denomination of the city of Dnepropetrovsk. Yet the last three tactics are apparently in use. Moreover, the game tactics initially serves as a basis for new denominations and is generated by a common, long-held trend of discursive prac- 
tices in mass media language; thus, by the language game at all levels [Annenkova 2018; Annenkova, Remchukova 2018]. However, the fact is that the game for the sake of it is, of course, impossible in media discourse [Bragina 2006]. Sooner or later it becomes ideological argumentation, which in this case is demonstrated by an invective attitude of such linguistic ludic naming. The result is a change of linguistic and cultural context in the understanding of certain extra-linguistic processes which include what is happening to the comprehension of the Ukrainian crisis by Russian and Ukrainian citizens. Thus, the artificially constructed historical separation of Russia and Ukraine, which was proposed as an artificial project of the Austro-Hungarian Empire, is being further entrenched as a naturally established cultural and historical difference. The functioning of the language game when naming as an invective within the media the "Ukraine" media topos undoubtedly leads towards the formation of a new archetypal external topos "Russia/Ukraine" (similar to well-known external toposes which include "Word/Act", "life/death", "Being/consciousness", etc., and even those like "Russia/West", "Russia/East", which are perceived today as less antagonistic). What is more, the framework of this neotopos drifts towards absolute antagonism. It should be noted that this antagonism is not only recorded by the media, but also supported, cemented, and largely initiated. In terms of media rhetoric one can say that the transformation of toposes and the formation of new media toposes demonstrate new cultural and argumentation dominants in the contemporary media space.

In 2017 a bachelor student M. E. Sleptsova defended a thesis (supervised by associate professor L. N. Pavlova) on "Political discourse in Russian talk shows (using the example of a discussion on the Ukrainian crisis)" at the Ammosov North-Eastern Federal University in Yakutsk. The work is a framing research of political discourse, embedded into media discourse at the level of political talk show genre. In addition to the results obtained by the researcher, the methodology of the analysis which was proposed by Dennis Liechtenstein, a professor at the Zeppelin University (Munich, Germany) is of particular interest as well. The study analyzed Russian and German talk shows. Comparative analysis showed both differences and similarities in the presentation of topical political material by both Russian and German television channels [Fiodorova 2011]. This is fundamentally important for understanding that media discursive processes are rather monolithic regardless of the country of origin for those media and of political preferences of those who generate media texts (from the journalist to the producer to the media owner). Rhetorical approaches are actually almost the same everywhere.

Therefore, according to M.Sleptsova, defamation is the most common phenomenon in Russian political discourse. The examples of naming cited above clearly fit into this concept of media discursive activity. The strategies, for example, that are highlighted by D. R. Akopova (lowering, raising, theatricality) [Akopova 2013: 403] are apparent in denominations within the "Ukraine" media topos.

According to the copyright laws we propose a table (see Appendix) of the thesis cited above in English, since it belongs not so much to M. E. Sleptsova and the university as to D. Liechtenstein, and was compiled for his larger research (the table is given in a shorter version because not all of its data is important and interesting for this discussion) [Sleptsova 2017: Appendix Codebook].

Research Results and Conclusions. To sum up, one can conclude that Ukraine as a media topos has filled in not only Russian and Ukrainian media but also that of other countries, including Germany. Diverse aspects of this topic demonstrate the peculiar 
structuring of media discourse in a certain direction, namely in shaping the image of Ukraine, the image of Russia with regard to Ukraine, as well as with regard to the whole Western world and Western nations, and the formation of the image of the West and its relations with Russia seeing the crisis in Ukraine. Needless to say, the analysis of the presented frames and toposes is still to be completed. However, the very attention to such modeling of media discourse (even within the framework of one genre), suggests that the analysis of culture-forming toposes and their transformation in media discourse is one of the most important areas of media rhetoric.

\section{References}

Akopova, D. R. (2013). Strategii i taktiki politicheskogo diskursa [Strategies and Tactics of Political Discourse]. Nizhny Novgorod: N. I. Lobachevsky Nizhny Novgorod State University Press. (In Russian)

Annenkova, I. V. (2011). Mediadiskurs XXI veka: lingvofilosofskii aspekt iazyka SMI [Media Discourse of the 21st Century. Linguophilosophical Aspect of the Media Language]. Moscow: Moscow State University Press. (In Russian)

Annenkova, I. V. (2018). Naming as a Type of Media Space: Transformation of Meanings in Mass Media. Ottawa: Carleton University.

Annenkova, I. V., Remchukova, E. N. (2018). Naming in Different Areas of Communication Field. Collective monograph. Ottawa: Carleton University.

Bragina, N.G. (2006). Metafory igry v opisaniiakh mira cheloveka (mezhlichnostnye otnosheniia) [Game Metaphors in Describing the Human World (Interpersonal Relations)]. Moscow: Indrik. (In Russian)

Bubnova, I. A., Krasnykh, V.V., Ufimtseva, N. V., Zykova, I.V. (2017). (Neo)psikholingvistika i (psikho) lingvokul'turologiia: novye nauki o cheloveke govoriashchem [(Neo)Psycholinguistics and (Psycho)Linguoculturology: the New Sciences about the Person Speaking]. Collective monograph. Moscow: Gnozis. (In Russian)

Fiodorova, L. L. (Ed.). (2011). Konflikt v iazyke i v kommunikatsii [Conflict in Language and Communication]. Moscow: Russian State University for the Humanities Publishing Center. (In Russian)

Goddard, C. (2008). Cross-Linguistic Semantics. Amsterdam: John Benjamins.

Habermas, J. (2008). Von der Weltbildern zur Lebenswelt [From the Pictures of the World to the Living World]. Duisburg: Universität Duisburg-Essen.

Khazagerov, G. G. (2002). Politicheskaia ritorika [Political Rhetorics]. Moscow: Nikkolo-Mediia. (In Russian)

Khazagerov, G. G. (2009). Myshlenie, prinesennoe v zhertvu ubezhdeniiu [Thinking Sacrificed in the Name of Conviction]. Retrieved from http://www.khazagerov.com/cultural-language-situation/75-convince.

Krasnykh, V. V. (2017). Novye nauki o cheloveke govoriashchem: otvet na vyzov nashego vremeni. Vstupitel'naia stat'ia [New Science about the Person Speaking: Response to the Challenge of Our Time. Introductory Article]. Moscow: Gnozis. (In Russian)

Kreuz, R. J., Roberts, R.M. (1995). Two Cues for Verbal Irony: Hyperbole and the Ironic Tone of Voice. Metaphor and Simbolic Activity, 10(1), 21-31.

Pavlova, A. V. (2013). Svedeniia o kul'ture i "etnicheskom mentalitete" po dannym iazyka [Cultural and "ethnic mentality" information according to language data]. Saint Petersburg: Antologiia. (In Russian)

Sleptsova, M.E. (2017). Politicheskii diskurs $v$ rossiiskikh tok-shou (na primere obsuzhdeniia ukrainskogo krizisa) [Political Discourse in Russian Talk Shows (Using the Example of Discussion on the Ukrainian Crisis]. Bachelor's Thesis. Yakutsk. (In Russian)

Received: November 15, 2018

Accepted: January 15, 2019

Author's information:

Irina V. Annenkova - Dr. Sci. in Philology, Prof.; anneirina@yandex.ru 


\title{
Система медиатопосов современного медиадискурса России как отражение и трансформация русских культурных архетипов
}

\author{
И. В. Анненкова \\ Московский государственный университет, \\ Российская Федерация, 125009, Москва, Моховая ул., 9
}

Для цитирования: Annenkova, I. V. (2019). The System of Russian Contemporary Media Discourse Media Toposes as a Reflection and a Transformation of Russian Cultural Archetypes. Медиалингвистика, 6(1), 87-102. https://doi.org/10.21638/spbu22.2019.107 (In English)

Делается акцент на том, что медиариторический подход изучения современных медиадискурсивных практик должен быть внесен в новую парадигму лингвистических наук о человеке говорящем. В связи с этим рассматривается проблема формирования медиатопосов в современных СМИ на базе уже имеющихся архетипичных топосов русской культуры. Интерпретация и трансформация национальной топики - одна из сторон стратегической деятельности современных медиа, формирующих новую картину мира, которую мы сегодня называем медиакартиной мира. На примере нового медиатопоса «Украина» осмысляются процессы изменения ментальных доминант в современном сознании русских. Языковая игра со словами, относящимися к полю этого медиатопоса, демонстрирует нам таргетирование в первую очередь такой речеповеденческой доминанты, как агрессия, и выражается в креативной инвективе. Такая дискурсная практика становится нормой для русскоязычного пространства (особенно в его интернет-сегменте) и явно демонстрирует нам важнейшую функцию языковой игры в СМИ - функцию идеологической аргументации. Эта функция должна быть признана универсальной медиадискурсивной категорией, что видно из анализа медиапространства России, Украины, а также зарубежных стран. Помимо этого, в русле важнейших медиадискурсивных стратегий десакрализации и гедонизации языковая игра, ставшая за последние 25-30 лет главным лингвистическим трендом современного медиадискурса, рассматривается как явление неоднозначное. С одной стороны, языковая игра демонстрирует потенциал самого языка. Понимание этого потенциала в языке - залог творческого отношения журналистов к нему. С другой стороны, такая языковая игра, лишенная глубинного смысла, существующая в качестве своеобразной словесной эквилибристики, лишает язык его важнейшей сущности - смыслоопределяющей и ментальноформирующей. Более того, она может не просто трансформировать, но и деформировать архетипические доминанты в ментальности народа. Особенно важно отслеживать креативную инвективу в качестве инструмента разрушения изнутри архетипических доминант культуры.

Ключевые слова: медиатопос, медиадискурс, языковая игра, нейминг, креативная инвектива.

Статья поступила в редакцию 15 ноября 2018 г.; рекомендована в печать 15 января 2019 г.

Контактная информация:

Анненкова Ирина Васильевна - д-р филол. наук, проф.; anneirina@yandex.ru 


\section{APPENDIX}

\section{Framing Topical Structure of 'Ukraine' Media Topos in Diverse National Media Systems’ Media Discourse}

\begin{tabular}{|c|c|c|}
\hline $\begin{array}{c}\text { Focus of } \\
\text { frames }\end{array}$ & Groups of frames & Frames (frame elements and content examples) \\
\hline \multirow{6}{*}{$\begin{array}{l}\text { Situation in } \\
\text { Ukraine }\end{array}$} & \multicolumn{2}{|c|}{ Situation in Ukraine in general } \\
\hline & \multirow{5}{*}{ Economic problems } & $\begin{array}{l}\text { Ecomomic structures } \\
\text { Problem: [U]kraine suffers from weak economy } \\
\text { Cause: De facto government default, corruption } \\
\text { Blame: In some cases, Putin's maintence of } \\
\text { Ukraine's dependence [on] Russia } \\
\text { Treatment: EU (and Russia) must stabilize } \\
\text { [Ukraine's] economy }\end{array}$ \\
\hline & & $\begin{array}{l}\text { [Yawning gap] } \\
\text { Problem: Ukraine suffers from weak economy } \\
\text { Cause: long-lasting systematic mismanagment, } \\
\text { incompetence and corruption } \\
\text { Blame: former [governmentals], oligarchs, political } \\
\text { system } \\
\text { Treatment: Ukraine's problems cannot be } \\
\text { solved. Russia should concentrate on its own } \\
\text { ecomomic problems }\end{array}$ \\
\hline & & $\begin{array}{l}\text { Greedy oligarchs } \\
\text { Problem: Ukraine suffers from weak economy } \\
\text { Cause: corruption } \\
\text { Blame: oligarchs who influence the government } \\
\text { and thereby destroy the country in their } \\
\text { personal economic interests } \\
\text { Treatment: Reduce the oligarch's political } \\
\text { influence; cut off the oligarchs financial } \\
\text { [sources] }\end{array}$ \\
\hline & & Other economic frames \\
\hline & & $\begin{array}{l}\text { Desoriented Ukraine } \\
\text { Problem: Ukraine [doesn't] know if it belongs to } \\
\text { Russia or to the West } \\
\text { Cause: political strategies in the name of } \\
\text { oligarch's economic [interests] } \\
\text { Blame: Yanukovych, oligarchs } \\
\text { Treatment: Russia should cooperate with } \\
\text { Ukraine, but should not pay for Ukraine's } \\
\text { [loyalty] }\end{array}$ \\
\hline
\end{tabular}




\begin{tabular}{|c|c|c|}
\hline $\begin{array}{c}\text { Focus of } \\
\text { frames }\end{array}$ & Groups of frames & Frames (frame elements and content examples) \\
\hline \multirow{8}{*}{$\begin{array}{l}\text { Situation in } \\
\text { Ukraine }\end{array}$} & \multirow{5}{*}{ Political problems } & $\begin{array}{l}\text { Yanukovych lost Ukraine } \\
\text { Problem: Revolution in Ukraine brings parts of } \\
\text { the country closer to the West } \\
\text { Cause: Politics has escalated the Maidan protests } \\
\text { Blame: Yanukovych, the [Ukrainian] security service } \\
\text { Treatment: [Russia] should help the population } \\
\text { [in] Crimea that has not been affected by } \\
\text { revolution so far }\end{array}$ \\
\hline & & $\begin{array}{l}\text { Antidemocratic movement } \\
\text { Problem: Democracy in Ukraine is under threat } \\
\text { Cause: rebellion against the democratically } \\
\text { [elected] president; new [government lacks legitimacy] } \\
\text { Blame: protestors on Maidan } \\
\text { Treatment: [Russia] should help the population } \\
\text { [in] Crimea that has not been affected by } \\
\text { the revolution so far }\end{array}$ \\
\hline & & $\begin{array}{l}\text { Freedom struggle [against] Kiev's hegemony } \\
\text { Problem: Government [in] Kiev is not a } \\
\text { government of nation unity } \\
\text { Cause: Not a legitimate government } \\
\text { Blame: West } \\
\text { Treatment: Formation [of] a government of } \\
\text { national unity }\end{array}$ \\
\hline & & $\begin{array}{l}\text { Right-wing radicalism } \\
\text { Problem: [Right-wing] forces were [instrumental] } \\
\text { in the coup in Ukraine } \\
\text { Cause: Opposition has lost control of Maidan } \\
\text { Blame: EU looking the other way } \\
\text { Treatment: Do something against right-wing } \\
\text { extremist groups }\end{array}$ \\
\hline & & Other political frames \\
\hline & \multirow{3}{*}{$\begin{array}{l}\text { Ukrainian } \\
\text { population }\end{array}$} & $\begin{array}{l}\text { Human interest } \\
\text { Problem: Suffering and [destruction] in Ukraine } \\
\text { Cause: War } \\
\text { Blame: Russia and Putin } \\
\text { Treatment: Negotiations with international } \\
\text { participation }\end{array}$ \\
\hline & & $\begin{array}{l}\text { Population and social structure } \\
\text { Problem: Conflicts in the population }>\text { pro- } \\
\text { European vs. pro-Russian } \\
\text { Cause: Historically grown conflicts in the population } \\
\text { Blame: - } \\
\text { Treatment: decentralization }\end{array}$ \\
\hline & & Other frames [of] domestic affairs \\
\hline
\end{tabular}




\begin{tabular}{|c|c|c|}
\hline $\begin{array}{l}\text { Focus of } \\
\text { frames }\end{array}$ & Groups of frames & Frames (frame elements and content examples) \\
\hline \multirow{4}{*}{$\begin{array}{l}\text { Situation in } \\
\text { Ukraine }\end{array}$} & \multirow{3}{*}{$\begin{array}{l}\text { Separatists as the } \\
\text { main problem in } \\
\text { the peace building } \\
\text { process }\end{array}$} & $\begin{array}{l}\text { Russian stooges } \\
\text { Problem: Russia supports separatists with weapons } \\
\text { Cause: Russia’s geopolitical interests } \\
\text { Blame: Putin and Russia } \\
\text { Treatment: International inspections } \\
\end{array}$ \\
\hline & & $\begin{array}{l}\text { Separatist agression } \\
\text { Problem: Separatists agression } \\
\text { Cause: Conflicts over strategic points } \\
\text { Blame: Both sides, but [mainly] separatists } \\
\text { Treatment: Russia must put more pressure on separatists }\end{array}$ \\
\hline & & Other frames on separatists as a problem \\
\hline & \multicolumn{2}{|c|}{ Other frame $[\mathrm{s}][$ of $]$ the situation in Ukraine } \\
\hline \multirow{4}{*}{$\begin{array}{l}\text { Interna } \\
\text { tensions / } \\
\text { global order }\end{array}$} & International tensio & ns/global order in general \\
\hline & \multirow{3}{*}{$\begin{array}{l}\text { Ukraine crisis as a } \\
\text { between global } \\
\text { players leads to } \\
\text { international } \\
\text { crisis }\end{array}$} & $\begin{array}{l}\text { [Pressure] from the EU } \\
\text { Problem: EU puts [pressure] on Ukraine for } \\
\text { political transformation and a close connection to } \\
\text { the EU instead of Russia; EU thereby interferes in } \\
\text { Ukrainian politics and [parliament] composition } \\
\text { Cause: economic interest of the EU; e.g. EU } \\
\text { needs cheap foreign [labor] from Ukraine for its } \\
\text { economy } \\
\text { Blame: the EU } \\
\text { Treatment: new Ukrainian [government] should } \\
\text { re-orient its politics from the EU to a close } \\
\text { relationship [with] Russia }\end{array}$ \\
\hline & & $\begin{array}{l}\text { US interests in Ukraine } \\
\text { Problem: US troops in Ukraine provoke Russia and } \\
\text { try to further escalate the conflict } \\
\text { Cause: the US's economic interests in this region } \\
\text { Blame: US companies such as BP, Shell and also government } \\
\text { Treatment: Russia has to stabilize Crimea and } \\
\text { other parts of Ukraine not affected by US } \\
\text { influence yet }\end{array}$ \\
\hline & & $\begin{array}{l}\text { Russia's sphere of influence } \\
\text { Problem: Russia puts pressure on the Ukrainian } \\
\text { president Yanukovych [to influence cooperation with] } \\
\text { Russia instead of the EU; ignores the Ukraine's } \\
\text { wish for togetherness with Europe and Russia } \\
\text { Cause: Russian self-[perception] as a power that } \\
\text { can make decisions in the name of Ukraine and } \\
\text { other states in its neighborhood abroad } \\
\text { Blame: Russia } \\
\text { Treatment: Russia should respect Ukraine as a } \\
\text { democratic and sovereign state and let } \\
\text { Ukrainian people decide about [their] own future }\end{array}$ \\
\hline
\end{tabular}




\begin{tabular}{|c|c|c|}
\hline $\begin{array}{l}\text { Focus of } \\
\text { frames }\end{array}$ & Groups of frames & Frames (frame elements and content examples) \\
\hline & & $\begin{array}{l}\text { [Conflict of] interests (de-escalation) } \\
\text { Problem: Ukraine is torn between claims from } \\
\text { Russia and the EU } \\
\text { Cause: Russia, the EU } \\
\text { Blame: mutual distrust between the global } \\
\text { players and their competing interests in the region } \\
\text { Treatment: Negotiations and communication } \\
\text { between the conflicting parties }\end{array}$ \\
\hline & & $\begin{array}{l}\text { Western intervention } \\
\text { Problem: Crimea was Putin's response to actions } \\
\text { of the West } \\
\text { Cause: Strategic plan of [the] US and NATO } \\
\text { Blame: West, US, EU } \\
\text { Treatment: All groups must be disarmed in } \\
\text { Eastern and Western Ukraine }\end{array}$ \\
\hline & & $\begin{array}{l}\text { Civil [insurrection] } \\
\text { Problem: Peaceful Maidan protesters were beaten } \\
\text { up } \\
\text { Cause: Despotism under Yanukovych } \\
\text { Blame: Russia, Oligarchs } \\
\text { Treatment: Respect and protect the people } \\
\end{array}$ \\
\hline & & Other frame[s] [of] Ukraine as a battelfield \\
\hline & \multirow{3}{*}{$\begin{array}{l}\text { Russia's aggresion is } \\
\text { a threat to } \\
\text { International } \\
\text { security }\end{array}$} & $\begin{array}{l}\text { Despotic Russia strives for global power } \\
\text { Problem: Putin wants to rebuild Soviet Union } \\
\text { Cause: Russia has always seen itself as a super power } \\
\text { Blame: Putin [is an] anti-democrat and [a] dictator } \\
\text { Treatment: [Negotiations] }\end{array}$ \\
\hline & & $\begin{array}{l}\text { Violation of international law } \\
\text { Problem: Russia violates self-determination of } \\
\text { Ukraine } \\
\text { Cause: Russia'a irrational [sense] of threat } \\
\text { Blame: Russia/Putin } \\
\text { Treatment: Economic sanctions } \\
\end{array}$ \\
\hline & & Other frame[s] [of] Russia's aggression \\
\hline & \multirow{2}{*}{$\begin{array}{l}\text { The West threatens } \\
\text { security in Europe }\end{array}$} & $\begin{array}{l}\text { West is expanding } \\
\text { Problem: West expansion threatens Russia's } \\
\text { security } \\
\text { Cause: Cold war thinking on the part of the West } \\
\text { Blame: the West (US, NATO, EU) } \\
\text { Treatment: Admit mistakes and change perspective }\end{array}$ \\
\hline & & $\begin{array}{l}\text { US imperialism } \\
\text { Problem: Aggressive US instrumentalized NATO } \\
\text { Cause: Geopolitical interests of the US } \\
\text { Blame: US } \\
\text { Treatment: EU needs to find own strong position }\end{array}$ \\
\hline
\end{tabular}




\begin{tabular}{|c|c|c|}
\hline $\begin{array}{c}\text { Focus of } \\
\text { frames }\end{array}$ & Groups of frames & Frames (frame elements and content examples) \\
\hline & & Strategic [mistakes] of European politics \\
\hline & & $\begin{array}{l}\text { Problem: EU has no plan of action } \\
\text { Cause: EU did not act with necessary historical } \\
\text { consciousness } \\
\text { [Treatment]: Admit mistakes }\end{array}$ \\
\hline & & Other frame $[\mathrm{s}][\mathrm{of}]$ the West [threatenings] \\
\hline & \multirow{3}{*}{$\begin{array}{l}\text { Policy options for } \\
\text { the West }\end{array}$} & $\begin{array}{l}\text { Real politics } \\
\text { Problem: Ukraine crisis threatens peace in Europe } \\
\text { Cause: diverging political interests and mutual } \\
\text { district } \\
\text { Blame: - } \\
\text { Treatment: Pragmatic real politics }\end{array}$ \\
\hline & & $\begin{array}{l}\text { West must show strength } \\
\text { Problem: Hesitant West and aggressive Russia have } \\
\text { [different] laws and values } \\
\text { Cause: Western statesmen with no profile have } \\
\text { never experienced war } \\
\text { Blame: Criticism of Western statesmen } \\
\text { Treatment: Policy of deterrence }\end{array}$ \\
\hline & & Other frame[s] [of] Western policy options \\
\hline & \multirow{3}{*}{$\begin{array}{l}\text { Global structures } \\
\text { threaten security }\end{array}$} & $\begin{array}{l}\text { Great power politics } \\
\text { Problem: Ukraine crisis is a conflict between great } \\
\text { powers } \\
\text { Cause: Expansion of spheres of interest } \\
\text { Blame: Russia, US, NATO, EU } \\
\text { Treatment: Clear rules of diplomacy }\end{array}$ \\
\hline & & $\begin{array}{l}\text { New world order } \\
\text { Problem: Struggles for independence that are } \\
\text { typical [for a] multipolar word order } \\
\text { Cause: No sufficient world order after the Cold War } \\
\text { Blame: - } \\
\text { Tretment: Restructuring political order in Europe with } \\
\text { the inclusion of [the EU] }\end{array}$ \\
\hline & & Other frame[s] [of] global security [threatenings] \\
\hline & & $\begin{array}{l}\text { US's attack against Russia } \\
\text { Problem: the US [has] initiated war in Ukraine to } \\
\text { provoke Russia for reactions and then declare a new } \\
\text { Cold War against Russia } \\
\text { Cause: US's interest in foreign policy; US strives for } \\
\text { obtaining its status [of] the only world power, [the] US [is interested } \\
\text { in weakening] } \\
\text { Russia in world politics and economy } \\
\text { Blame: the US } \\
\text { Treatment: Russia should resist by unifying the } \\
\text { slavish states and concidering military }\end{array}$ \\
\hline
\end{tabular}




\begin{tabular}{|c|c|c|}
\hline $\begin{array}{l}\text { Focus of } \\
\text { frames }\end{array}$ & Groups of frames & Frames (frame elements and content examples) \\
\hline & \multirow[t]{3}{*}{$\begin{array}{l}\text { International crisis } \\
\text { leads to Ukraine } \\
\text { crisis }\end{array}$} & $\begin{array}{l}\text { Disregard of International Law } \\
\text { Problem: [the] US and [the] EU have double [standards] in their } \\
\text { foreign policy (Cosovo vs. Ukraine) } \\
\text { Cause: US's interest in foreign policy } \\
\text { Blame: the US, the EU } \\
\text { Treatment: Russia should resist }\end{array}$ \\
\hline & & $\begin{array}{l}\text { Russian provocation } \\
\text { Problem: anti-Russian atmosphere in the US and } \\
\text { EU countries } \\
\text { Cause: Reaction to the Russian confrontational } \\
\text { action[s] in Ukraine and its open accusations against the US } \\
\text { Blame: Russia } \\
\text { Treatment: Russia should make compromises in } \\
\text { Ukraine to drop its New Russia project }\end{array}$ \\
\hline & & $\begin{array}{l}\text { Cooperating in World Politics (de-escalating) } \\
\text { Problem: heated atmosphere in international } \\
\text { relations } \\
\text { Cause: misunderstandings between Russia and the } \\
\text { West that can be explained by Ukrainian } \\
\text { representatives misinforming the West } \\
\text { Treatment: de-escalation and negotiations between } \\
\text { Russia and the West about further state of } \\
\text { Ukraine; West called to recognize the Crimean } \\
\text { referendum's result[s] }\end{array}$ \\
\hline & \multirow{3}{*}{$\begin{array}{l}\text { Media and public } \\
\text { opinion }\end{array}$} & $\begin{array}{l}\text { Anti-Russian propoganda } \\
\text { Problem: anti-Russian hysteria and Russophobia in } \\
\text { Ukraine and in the West endanger peace } \\
\text { Cause: information war against Russia inside } \\
\text { Ukraine but also inside Western [countries] } \\
\text { Blame: Ukrainian elites and Western stakeholders, } \\
\text { the media } \\
\text { Treatment: Russia should engage in information } \\
\text { war by actively [communicating] information and } \\
\text { [interpreting it] to the [countries' public] }\end{array}$ \\
\hline & & $\begin{array}{l}\text { Russian propoganda } \\
\text { Problem: Russian propoganda } \\
\text { Cause: Putin wants to devide Ukraine using anti- } \\
\text { Western propoganda } \\
\text { Blame: Putin, the media } \\
\text { Treatment: - }\end{array}$ \\
\hline & & $\begin{array}{l}\text { Rhetoric of escalation } \\
\text { Problem: Rhetoric fuels the conflict } \\
\text { Cause: Players do not believe in danger of hot war } \\
\text { Blame: media, western politicians } \\
\text { Treatment: [Objectification/rationalization of] the debate }\end{array}$ \\
\hline
\end{tabular}




\begin{tabular}{|c|c|c|}
\hline $\begin{array}{l}\text { Focus of } \\
\text { frames }\end{array}$ & Groups of frames & Frames (frame elements and content examples) \\
\hline & & $\begin{array}{l}\text { Biased Western media } \\
\text { Problem: German media fails to show the whole } \\
\text { picture of the crisis } \\
\text { Cause: Situation is complex and difficult to overview, } \\
\text { [culturally] embedded stereotypes } \\
\text { Blame: - } \\
\text { Treatment: German media should show the whole } \\
\text { picture }\end{array}$ \\
\hline & & Other frame $[\mathrm{s}]$ of media and public opinion \\
\hline & \multirow[t]{2}{*}{ Russian problems } & $\begin{array}{l}\text { Russia's weakness } \\
\text { Problem: Russia is economically isolated and is not } \\
\text { able to stand a new [C]old [War] } \\
\text { Cause: Russian passivity during the last decades; } \\
\text { politics [have] not developed a political vision and [have] } \\
\text { failed to strengthen the Russian [economy] } \\
\text { Blame: Russian politics } \\
\text { Treatment: Russia should become more active [in] its } \\
\text { political and economic development }\end{array}$ \\
\hline & & Other Russian problems \\
\hline & \multicolumn{2}{|c|}{ Other frame[s] [of] the [international] tensions/global order } \\
\hline
\end{tabular}

